\title{
A new species of freshwater amphipod (Dogielinotidae, Hyalella) from Southeastern Brazil
}

\author{
Rafaela Bastos-Pereira and Alessandra A. P. Bueno
}

(RBP, AAPB) Universidade Federal de Lavras, Departamento de Biologia, Setor de Ecologia, Laboratório de Carcinologia. Campus Universitário, Centro, CEP 37200-000, Lavras, Minas Gerais, Brazil. E-mail: (RBP) rafaelabastospereira@gmail.com

\begin{abstract}
To the present 57 species of Hyalella were described for Americas, 15 of them found in Brazil, which is among the most diverse countries for this genus. This work aims to describe a new Hyalella species with benthic habits which is found in a water source on Southeastern Brazil. It is mainly characterized by a wide truncated process formed near the dactylus insertion on gnathopod 2, besides both coxal and sternall gills present on pereonits 2 to 7 . This work improves the knowledge on biodiversity about Hyalella species.
\end{abstract}

Key words: Biodiversity, Freshwater Crustacean, Taxonomy

\section{INTRODUCTION}

The diversity of Hyalella Smith, 1874 has increased substantially in the last years. To the present 57 species were described for Americas, 15 of them from Brazil, which is among the most diverse countries for this genus (González et al., 2006; Santos et al., 2008; Cardoso et al., 2011; Bastos-Pereira and Bueno, 2012; Rodrigues et al., 2012).

Most of Hyalella species are epigean, but some may be found in hipogean habitats and present troglomorphic or troglobiotic characteristics. In Brazil the majority of species is found in streams, lakes and rivers, while the others may be found inhabiting caves, wetlands and hypothelminorheic habitats (Pereira, 1989; Grosso and Peralta, 1999; González et al., 2006; Cardoso et al., 2011; Rodrigues et al., 2012). All records of Hyalella species from Brazil are located on Southern and Southeastern regions.

These freshwater amphipods may live associated to aquatic macrophytes or in debris deposits in the bottom of water courses. They feed on algae and bacteria associated to the sediment and to aquatic vegetation (Hargrave,
1970), besides animal and vegetal material in decomposition (Cooper, 1965). This work aims to describe a new Hyalella species with benthic habits which is found in a water source on Brazil.

\section{Material and Methods}

The new species was found in a water source belonging to Universidade Federal de Lavras - UFLA (2113'84”S/4458'66”W), municipality of Lavras, Minas Gerais state, located at $918 \mathrm{~m}$ of altitude. The stream formed by this water source presents mean deep of 30 $\mathrm{cm}$, predominantly sandy, with some leaf litter.

Specimens were collected with the aid of a net, separated from sediment and taken to the laboratory. The cephalothorax length was measured under stereoscopic microscope with a milimetric scale. Adult males and females were kept in ethanol 70\%, colored with Rose Bengal and dissected. Permanent slides of the appendages were mounted and morphological characteristics of paratypes were analyzed for description. Type material is deposited in the Crustacean Collection of Museu Nacional/ 
UFRJ) and on the Crustacean Collection of Laboratório de Carcinologia - UFLA.

The terminology for setae follows Zimmer et al. (2009). The new species description was made based on previous taxonomic works related to Hyalella species (Bastos-Pereira and Bueno, 2012; Santos et al., 2008; González et al., 2006; González and Watling, 2003a, b).

\section{Results ANd Discussion}

Family Dogielinotidae Gurjanova, 1953

Subfamily Hyalellinae Bulycheva, 1957

Genus Hyalella Smith, 1874

Hyalella minensis n. sp.

Material examined: Holotype male MNRJ 23388; Brazil, Minas Gerais state, Lavras, Universidade Federal de Lavras (2113'84”S/44058'66”W), April 2009: Bueno, A.A.P., Cardoso, G.M., Lovate, J.B., Martins, S.F., Bastos-Pereira, R. and Souza, A.C.C. colls. Allotype female MNRJ 23389 collected in the same point and date than holotype. Paratypes: UFLA253 (3今), MNRJ 23390 ( 1 slide $\left.{ }^{\top}\right)$, collected in the same point that holotype. August, 2010: Bastos-Pereira, R. and Rodrigues, S.G. colls.

Diagnosis: Acumination in coxae absent. Maxilla 2 inner plate with six pappose setae on inner margin. Gnathopod 1 carpus inner face with seven pappose setae; propodus inner face with five pappose setae, posterodistal margin with denticles in comb-scales. Gnathopod 2 propodus without comb-scales, palm shorter than posterior margin, palm with irregular edge with a wide truncated process formed near the dactylus insertion. Inner ramus of uropod 1 without curved seta. Coxal gills on segments 2 to 7 . Sternal gills on segments 2 to 7 .

\section{Description of male (Figs. 1-25)}

Holotype: total length $6.4 \mathrm{~mm}$ (cephalothorax $0.52 \mathrm{~mm}$ ). Body surface smooth. Epimeral plates round, not acuminated. Acumination in coxae absent.
Eyes pigmented, round (Fig 25).

Antenna 1 (Fig. 1): less than half body length, shorter than antenna 2, slightly longer than peduncle of antenna 2, peduncle longer than head. Flagellum of 11-12 articles, longer than peduncle. Aesthetasc on the $11^{\text {th }}$ article of flagellum.

Antenna 2 (Fig. 2): peduncle longer than head, article 3 short, article 4 subequal in length to article 5 of peduncle. Flagellum of 14-17 articles.

Mandible: basic amphipodan type (sensu Watling, 1993), but without palp; incisor toothed; right mandible setal row with two pappose setae (Fig. 3a); left lacinia mobilis with five teeth, setal row on left mandible (Fig. 3b) with four pappose setae; molar large, cylindrical, triturative, accessory seta present.

Lower lip (Fig. 4): outer lobes medially excavated, mandibular projections of outer lobes round.

Upper lip (Fig. 5): ventral margin round, distal margin covered by short setules.

Maxilla 1 (Fig. 6): palp uniarticulate, short, reaching less than half length distance between base of palp and tip of setae on outer plate; inner plate slender, smaller than outer plate, bearing two apical papposerrate setae; outer plate with less seven serrate setae.

Maxilla 2 (Fig. 7): inner plate with six pappose setae on inner margin, outer and inner plates with abundant setules.

Maxilliped (Fig. 8): inner plates apically rounded with four cuspidate and pappose setae; outer plates larger than inner plates, with apical and medial simple and pappose setae; palp longer than outer plate, with four articles; article 3 outer distal face with few simple setae, inner face with simple and pappose setae; article 4 unguiform, shorter than article 3, distal setae simple and longer than nail, inner border with simple setae; distal nail present.

Gnathopod 1 (Fig. 9a): subchelate; basis and merus with distal pappose setae with an accessory seta; carpus longer than wide with a wide posterior lobe forming a scoop like structure open to the inside with a border pectinate with several pappose setae, inner face with seven pappose setae; propodus (Fig. 9b) 

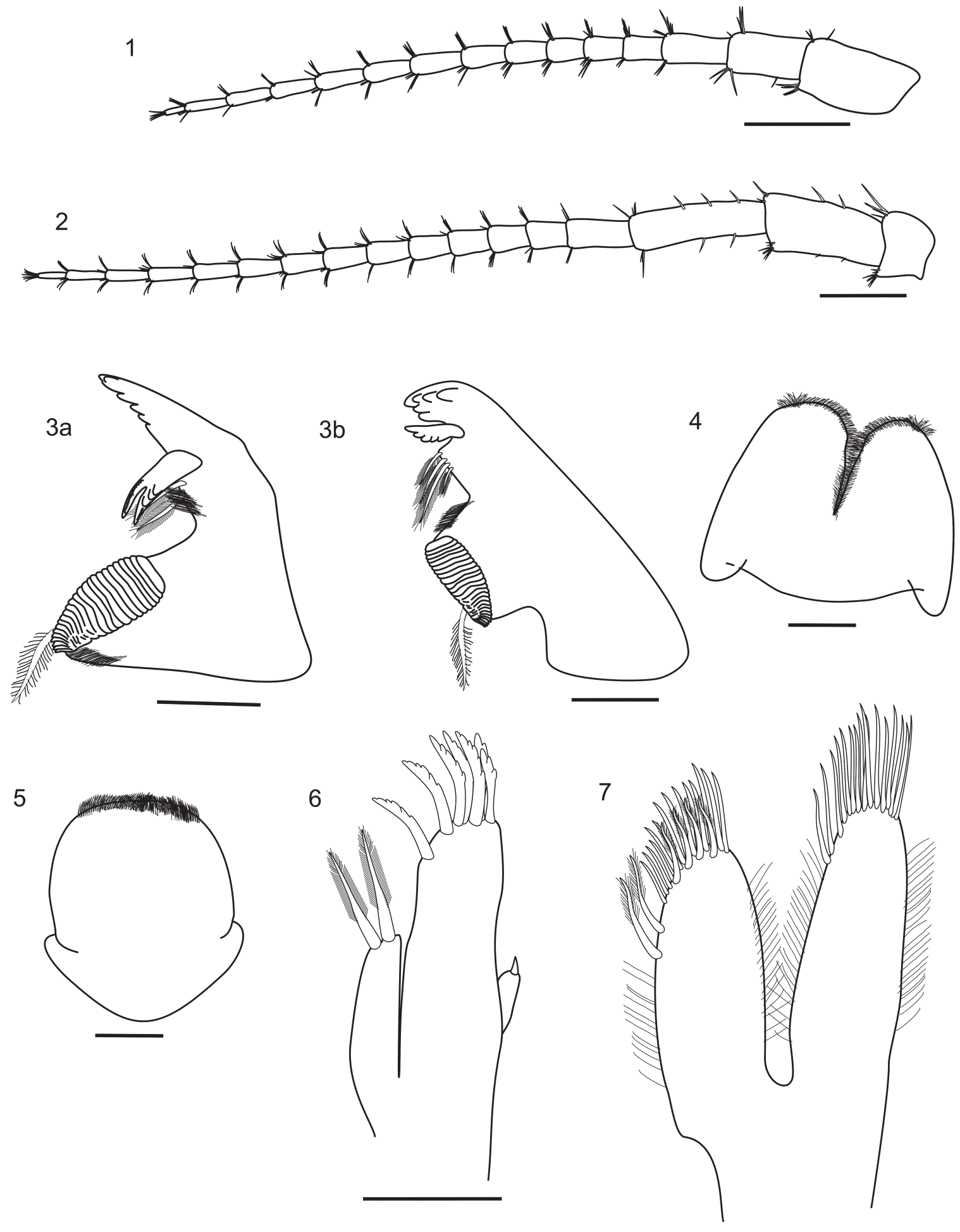

Figures 1 to 7. Hyalella minensis n. sp. Male: (1) antenna 1; (2) antenna 2; (3a) right mandible; (3b) left mandible; (4) lower lip; (5) upper lip; (6) maxilla 1; (7) maxilla 2. Scales: (1-2): 0.2mm, (3a-7): $0.1 \mathrm{~mm}$. 

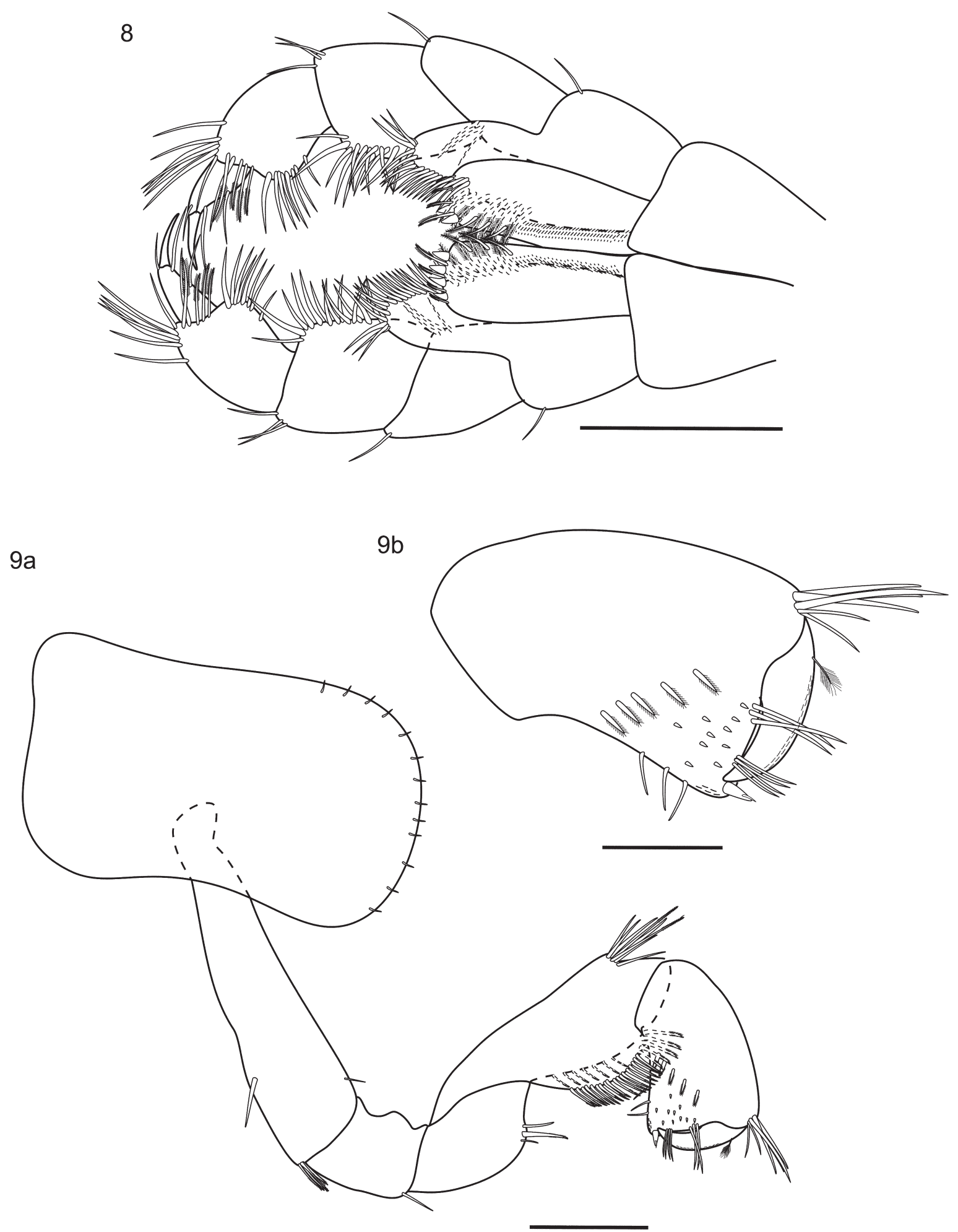

Figures 8 to 9. Hyalella minensis n. sp. Male: (8) maxilliped; (9a) gnathopod 1; (9b) detail of propodus and dactylus of gnathopod 2. Scales: (8 and 9b): $0.2 \mathrm{~mm},(9 \mathrm{a}): 0.1 \mathrm{~mm}$. 
length less than two times maximum width, hammer shape, inner face with five pappose setae and ten to sixteen small triangular setae, palm slope transverse, posterior distal corner with cuspidate setae with accessory seta, posterodistal margin with denticles in combscales; dactylus claw-like with denticles in comb-scales and one plumose seta.

Gnathopod 2 (Fig. 10a): subchelate, basis hind margin with few simple setae; merus with seven or more simple setae on posterior margin, distal corner rounded; carpus with posterior lobe elongated produced between merus and propodus, border pectinate with several pappose setae, with few denticles in comb-scales; propodus ovate, posterodistal and anterodistal borders without denticles in comb-scales, palm shorter than posterior margin, palm slope oblique with several short fine and some long simple setae, irregular edge with a wide truncated process formed near the dactylus insertion, posterodistal corner with two cuspidate setae with an accessory seta (Fig. 10b); dactylus claw-like, not fitting with palm, with several endal setae, without comb-scales.

Pereopods 3 to 7 (Figs. 11 - 15): simple, carpus and propodus posterior margin with cluster of cuspidate setae with accessory seta; dactylus less than half length of propodus. Pereopod 5 shorter than 4, peraeopod 6 longer than 5 , and pereopod 7 longer than 6 .

Pleopods (Fig. 16): not modified, peduncle wider and shorter than rami, with coupling hooks distally; rami with several plumose setae on both sides.

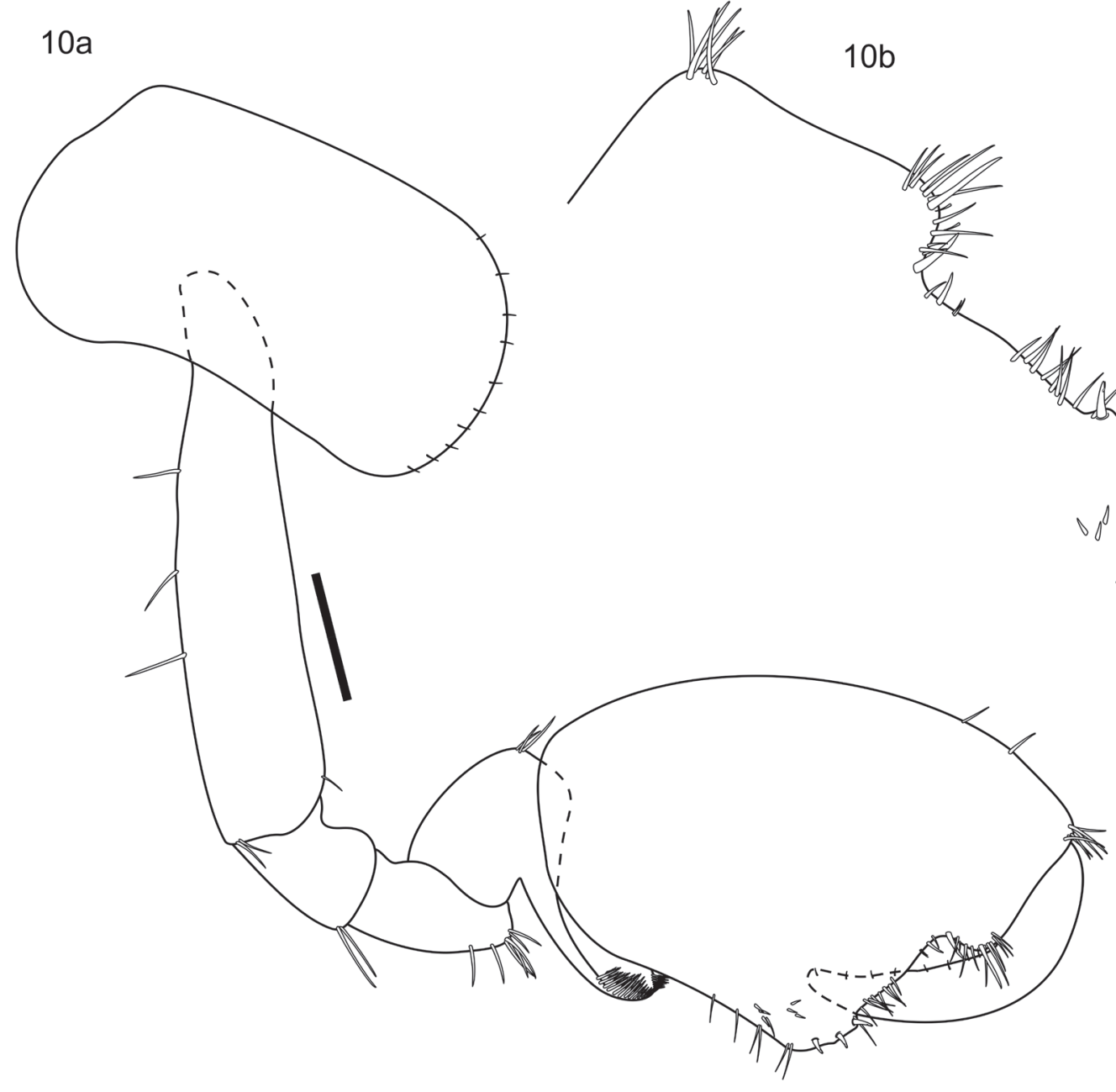

Figure 10. Hyalella minensis n. sp. Male: (a) gnathopod 2; (b) detail on the palm of propodus, a wide truncated process near dactylus insertion. Scales: (10a): $0.2 \mathrm{~mm},(10 \mathrm{~b}): 0.1 \mathrm{~mm}$. 
11

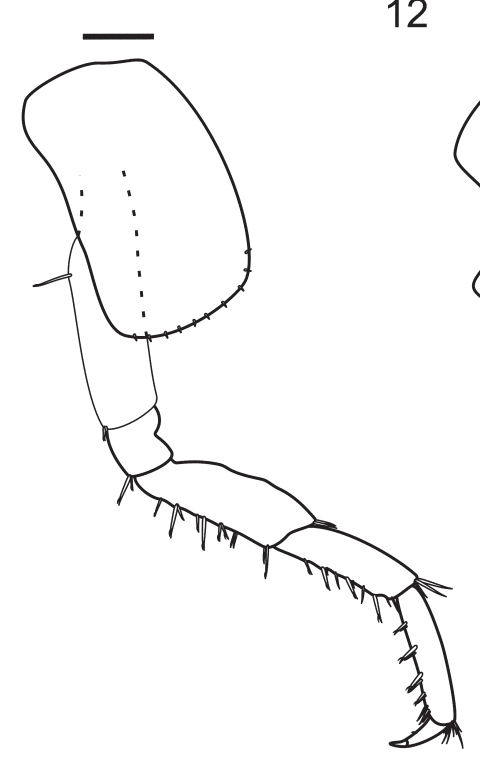

14
12

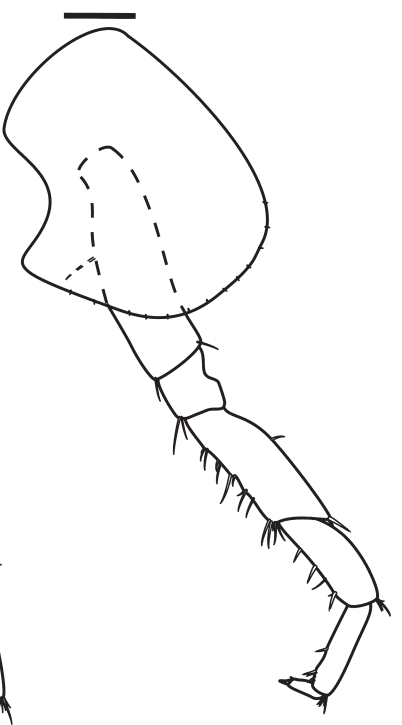

13

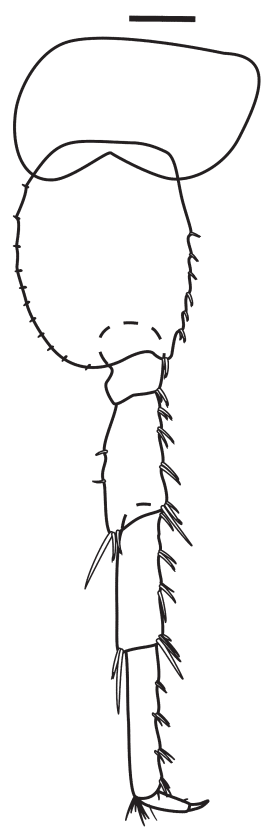

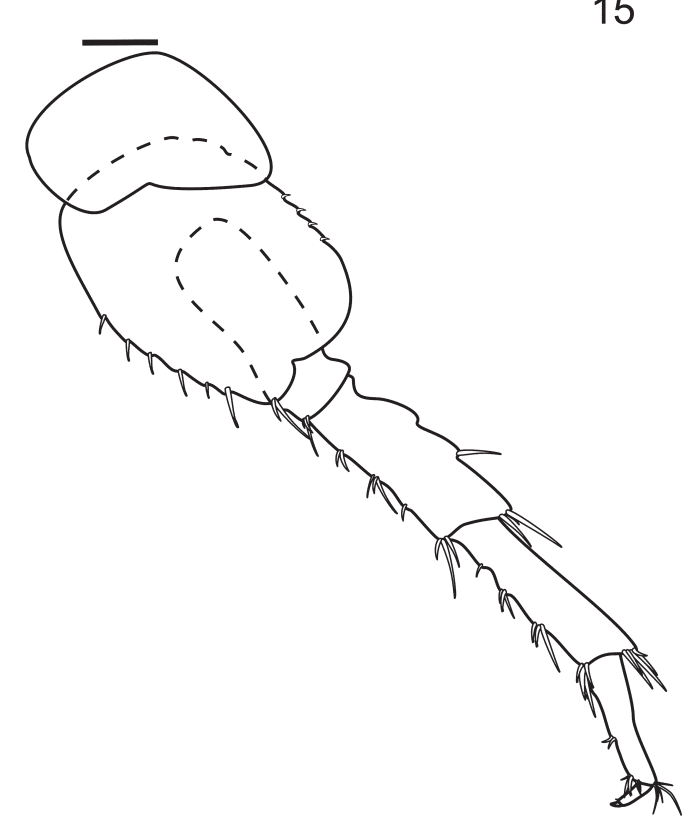

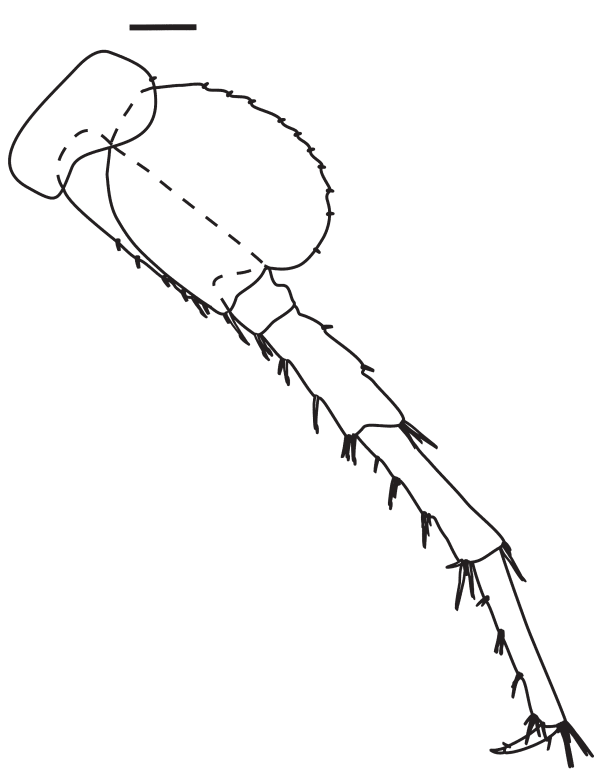

Figures 11 to 15. Hyalella minensis n. sp. Male: (11) peraeopod 3; (12) peraeopod 4; (13) peraeopod 5; (14) peraeopod 6; (15) peraeopod 7. Scales: (11-15): $0.2 \mathrm{~mm}$.

Uropod 1 (Fig. 17): longer than uropod 2; peduncle longer than rami, setation present; rami subequal in length; inner ramus with four dorsal cuspidate setae with accessory seta and four distal setae, two of them longer, without curved setae on inner side of inner ramus; outer ramus with three dorsal cuspidate setae with accessory seta, and seven distal setae.

Uropod 2 (Fig. 18): rami subequal in length; inner ramus with three dorsal and 6 distal cuspidate setae with accessory seta; outer ramus with four dorsal and four distal cuspidate setae with accessory seta; peduncle setation present.

Uropod 3 (Fig. 19): shorter than peduncle of uropod 1 , as long as peduncle of uropod 2; peduncle subrectangular, wider than ramus, with five distal cuspidate setae with accessory seta, no marginal setae; inner ramus absent; outer ramus uniarticulate, subequal to peduncle in length, basal width more than two times tip of ramus, six apical setae, four of 
16

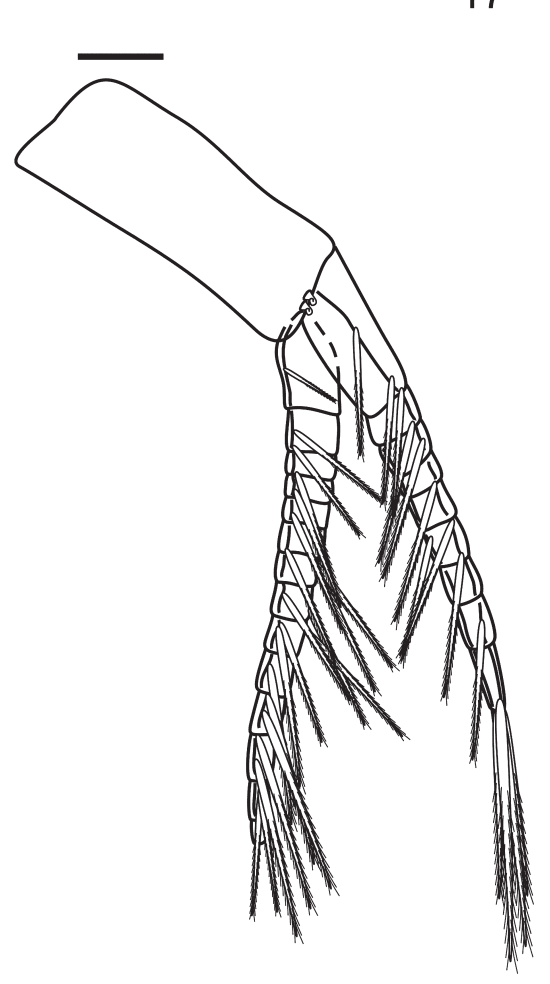

17
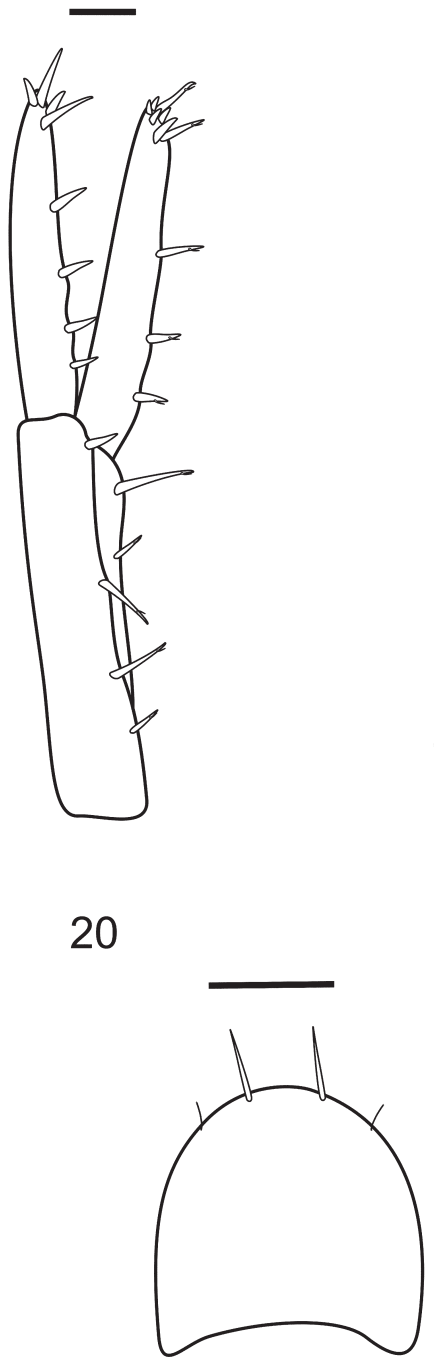

18

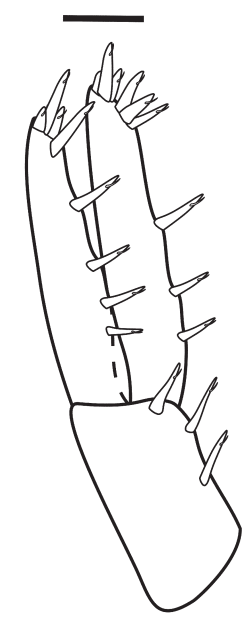

19

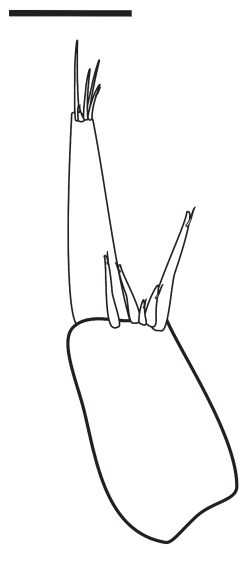

Figures 16 to 20. Hyalella minensis n. sp. Male: (16) pleopod; (17) uropod 1; (18) uropod 2; (19) uropod 3; (20) telson. Scales: (16-20): $0.1 \mathrm{~mm}$.

them simple, and two cuspidate, one of them with accessory seta.

Telson (Fig. 20): as wide as long, entire, rounded, with two widely apart simple setae with shorter setae close to them.

Coxal gills sac-like on segments 2 to 7 . Sternal gills tubular on segments 2 to 7 .

Female (Figs. 21-24; 26)

Total length: $4.4 \mathrm{~mm}$. Cephalothorax: $0.49 \mathrm{~mm}$ (Fig. 26).

Antenna 1 (Fig. 21): with 9-10 articles on flagellum.

Antenna 2 (Fig. 22): flagellum with 1314 articles.

Gnathopod 1 (Fig. 23): size similar to gnathopod 2; propodus longer than wide, with
5 pappose setae on inner face; propodus with comb-scales on posterodistal margin.

Gnathopod 2 (Fig. 24a): propodus subrectangular, longer than wide, with row of 4 serrate setae on medial face; propodus palm presents irregular edge with a wide truncated process formed near the dactylus insertion (Fig. 24b).

Etymology: The new species here described was found in a water source, called "mina" in Portuguese, Brazil. The specific epithet means "who comes from a water source".

Remarks: Among the species of Hyalella found in Southeastern Brasil, H. minensis is closely related to $H$. warmingi Stebbing, 1899. 
21

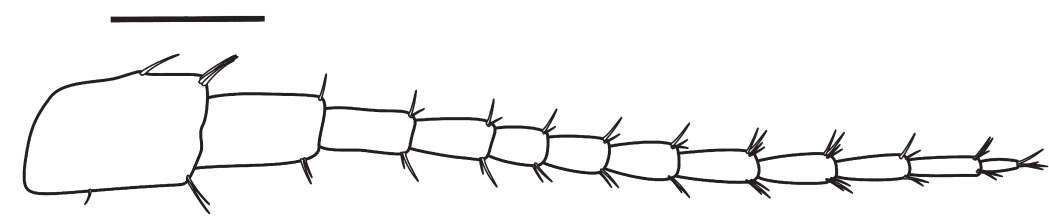

22

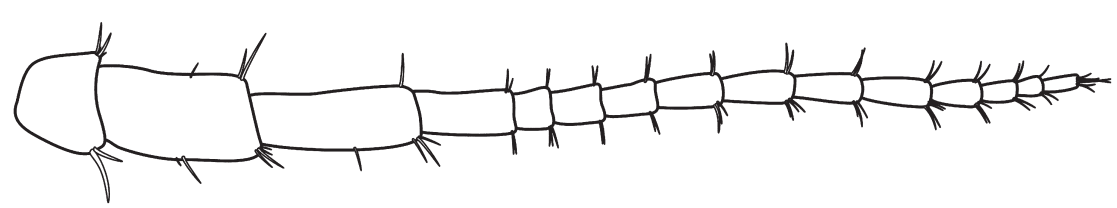

23

$24 a$

$24 b$
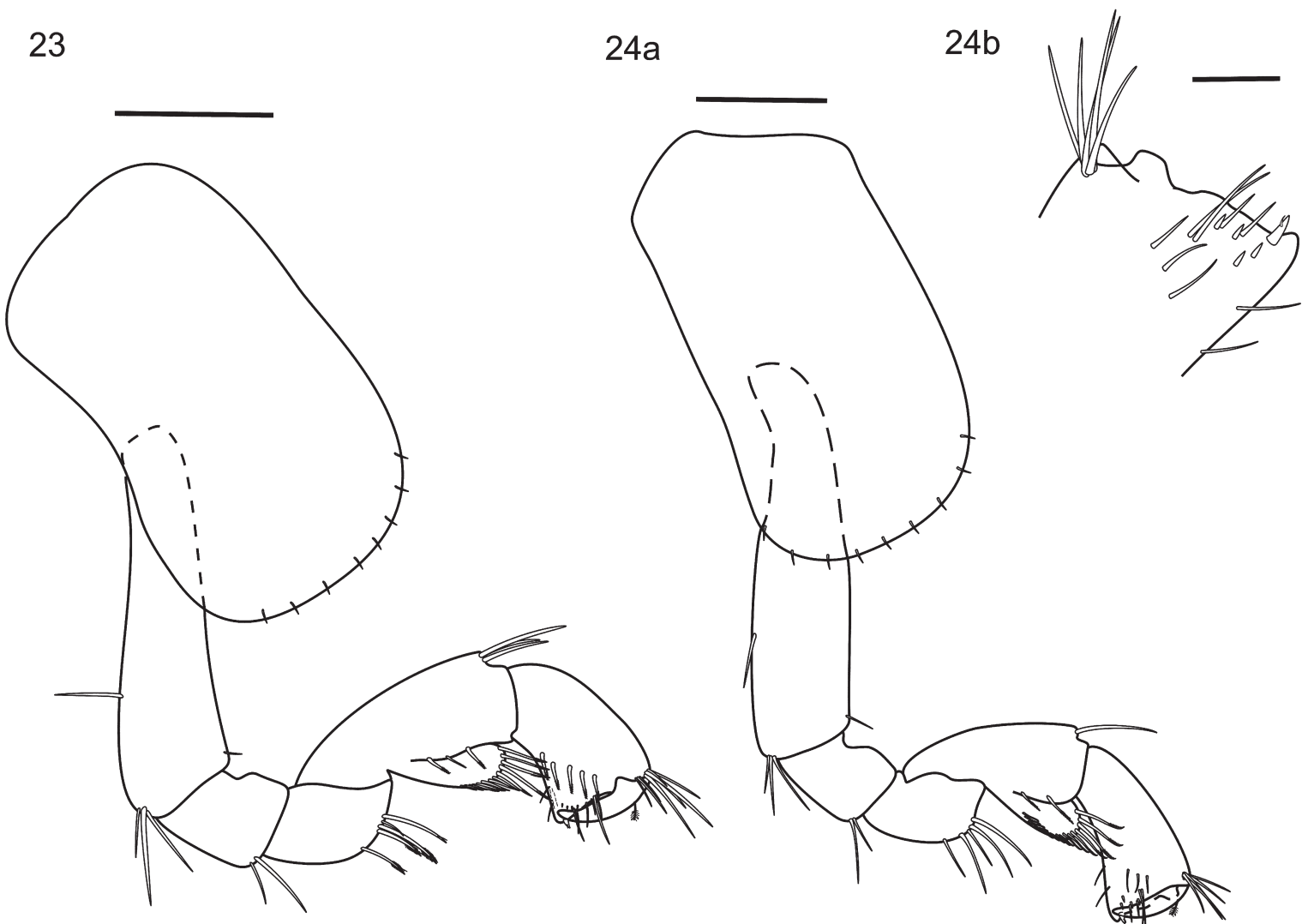

Figures 21 to 24. Hyalella minensis n. sp. Female: (21) antenna 1; (22) antenna 2; (23) gnathopod 1; (24a) gnathopod 2; (24b) detail on the palm of propodus, a wide truncated process near dactylus insertion. Scales: (21-24a): 0.2mm, (24b): $0.1 \mathrm{~mm}$.

Despite of the similar telson, the absence of curved seta on inner ramus of uropod 1 , palm of gnathopod 2 propodus shorter than posterior margin and the similar shape and setation of gnathopod 2 (all of this characters in males), which characteristics both species present, the process formed near the dactylus insertion on gnathopod 2 is wider and more truncated in $H$. minensis. Moreover, $H$. warming presents more pappose setae on the inner side of gnathopod 1 and coxal gills are present from pereonit 2 to 6 , while in $H$. minensis pairs of such gills may be observed until pereonit 7 .

The geographically nearest Hyalella species found in this region is $H$. longistila (Faxon, 1876) (Bastos-Pereira and Bueno, 2012). Despite of the absence of curved seta on uropod 1 and similar uropod 3, these species present differences mainly in relation 


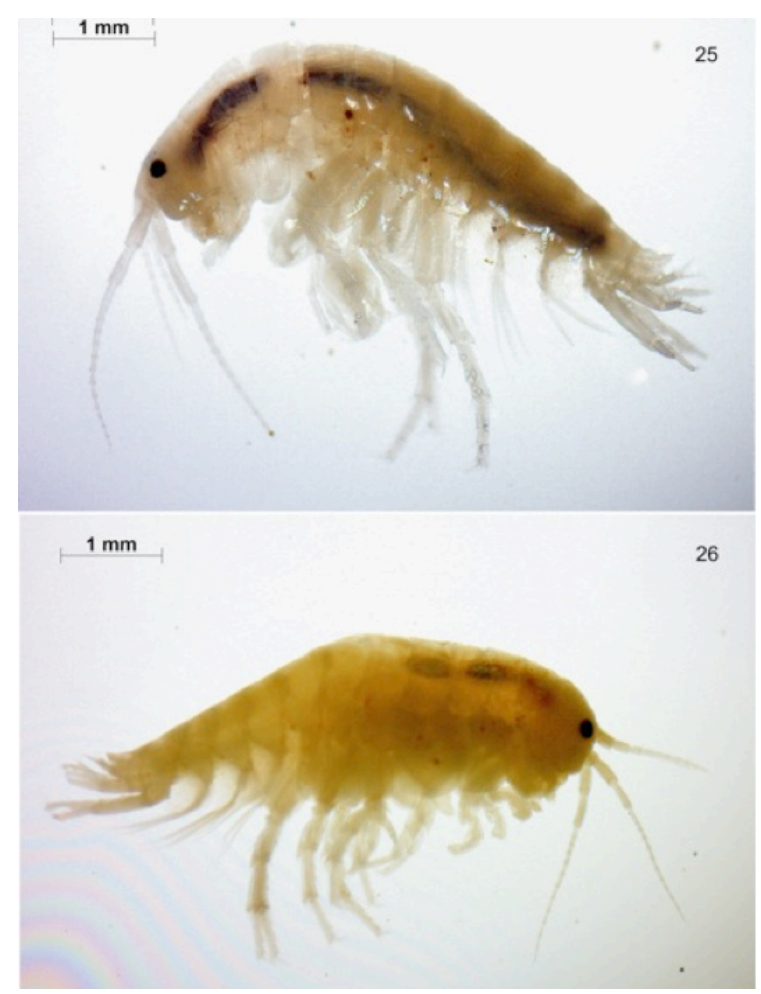

Figures 25 and 26. Hyalella minensis n. sp. (25) Holotype male; (26) Allotype female.

to female characteristics. The appendages of $H$. longistila generally are more elongated than in H. minensis. Regarding H. carstica BastosPereira and Bueno, 2012, although it presents the same number of coxal and sternal gills than $H$. minensis, they differ in relation to the curved seta present on uropod 1, besides abundant denticles in comb-scales present on gnathopod 1 of $H$. carstica. Such characteristics are not observed on $H$. minensis, it presents few combscales on gnathopod 1 propodus and dactylus and gnathopod 2 carpus.

Besides reinforcing the need to preserve the study place because of the water source and the new species which ecological and behavioral aspects are unknown, this work improves the knowledge about Hyalella diversity from Brazil.

ACKNOWLEDGMENTS - We thank Coordenação de Aperfeiçoamento de Pessoal de Nível Superior - CAPES for financial support granted to RBP and the team of Laboratório de Carcinologia - Universidade Federal de Lavras for helping with the collection of $H$. minensis, especially to Stella Gomes Rodrigues for helping with the montage of slides and illustrations. We also thanks the anonymous reviewers for comments in the early version of the manuscript.

\section{REFERENCES}

Bastos-Pereira, R. and Bueno, A.P.P. 2012. New species and new report of Hyalella Smith, 1874 (Crustacea: Amphipoda: Dogielinotidae) from southeastern Brazil. Zootaxa, 3350: 58-68.

Cardoso, G.M.; Bueno, A.A.P. and Ferreira, R.L. 2011. A new troglobiotic species of Hyalella (Crustacea, Amphipoda, Dogielinotidae) from Southeastern Brazil. Nauplius, 19(1): 17-26.

Cooper, W.E. 1965. Dynamics and production of a natural population of a freshwater amphipod Hyalella azteca. Ecological Monographs, 35: 377-394.

González, E.R. and Watling, L. 2003a. A new species of Hyalella from Brazil (Crustacea: Amphipoda: Hyalellidae), with redescription of three other species in the genus. Journal of Natural History, 37(17): 20452076.

González, E.R. and Watling, L. 2003b. A new species of Hyalella from Colombia, and the redescription of $H$. meinerti Stebbing, 1899 from Venezuela (Crustacea: Amphipoda). Journal of Natural History, 37(17): 2095-2111.

González, E.R; Bond-Buckup, G. and Araujo, P.B. 2006. Two new species of Hyalella from Southern Brazil (Amphipoda: Hyalellidae) with a taxonomic key. Journal of Crustacean Biology, 26(3): 355-365.

Grosso, L. and Peralta, M. 1999. Anfípodos de agua dulce sudamericanos. Revisión del género Hyalella Smith. I. Acta Zoologica Lilloana, 45(1): 79-98.

Hargrave, B.T. 1970. The utilization of benthic microflora by Hyalella azteca. Journal of Animal Ecology, 39: 427437.

Pereira, V.F.G. 1989. Uma nova espécie de anfípode cavernícola do Brasil - Hyalella caeca sp. n. (Amphipoda, Hyalellidae). Revista Brasileira de Zoologia, 6(1): 4955.

Rodrigues, S.G.; Bueno, A.A.P. and Ferreira, R.L. 2012. The first hypothelminorheic Crustacea (Amphipoda, Dogielinotidae, Hyalella) from South America. ZooKeys, 236: 65-80.

Santos, A.L.F; Araujo, P.B. and Bond-Buckup, G. 2008. New species and new reports of Hyalella (Crustacea, Amphipoda, Dogielinotidae) from Argentina. Zootaxa, 1760: 24-36.

Watling, L. 1993. Functional morphology of the amphipod mandible. Journal of Natural History 27: 837-849.

Zimmer, A.; Araujo, P.B. and Bond-Buckup, G. 2009. Diversity and arrangement of the cuticular structures of Hyalella (Crustacea: Amphipoda: Dogielinotidae) and their use in taxonomy. Zoologia, 26(1):127-142. 